Journal CleanWAS

Journal Homepage: http://www.razipublishing.com/journals/journal-cleanwas/

https://doi.org/10.26480/jcleanwas.01.2017.23.25

\title{
INHIBITORY EFFECT OF PIGMENT EXTRACT FROM SCENEDESMUS SP. ON FOOD SPIKED WITH FOODBORNE STAPHYLOCOCCUS AUREUS
}

Aisha Ishaq Gogoba*1, Hazel Monica Matias-Peralta1, Hatijah Basri1, Muhammad Muhammad Nmaya2 1 *Department of Technology and Heritage, Faculty of Science, Technology and Human Development, Universiti Tun Hussein Onn Malaysia, 86400 Parit
Raja, Batu Pahat, Johor, Malaysia 2Department of Physics, Faculty of Science, Technology and Human Development, Universiti Tun Hussein Onn Malaysia, 86400 Parit Raja, Batu Pahat, Johor, Malaysia *Corresponding author: hw120021@siswa.uthm.edu.my

This is an open access article distributed under the Creative Commons Attribution License, which permits unrestricted use, distribution, and reproduction in any medium, provided the original work is properly cited

\section{ARTICLE DETAILS}

Article history:

Received 27 September 2016

Accepted 13 December 2016

Available online 10 January 2017

Keywords:

Food, pigment extract, Scenedesmus sp., Staphylococcus aureus

\section{ABSTRACT}

Foodborne diseases are a recognized problem worldwide and the search is on to discover novel antimicrobial agents from natural sources that can replace the use of synthetic antimicrobial compounds. One of such sources are microalgae. The antibacterial efficacy of pigment extract from Scenedesmus sp. was tested against foodborne Staphylococcusaureus. The extract was prepared using $90 \%$ acetone and varying amounts was added to food suspension spiked with a known volume of the bacteria. Antibacterial activity was observed and evaluated through bacterial colony counts. Uncountable bacterial colonies were observed in the sample with $0.41 \mathrm{mg} / \mathrm{ml} \mathrm{and} 0.81$ $\mathrm{mg} / \mathrm{ml}$ concentration of pigment extract as they were TMTC and there was no growth of bacterial colonies in samples with $2.83 \mathrm{mg} / \mathrm{ml}-4.05 \mathrm{mg} / \mathrm{ml}$ concentration of pigment extract.The results of this study suggest that Scenedesmus sp. is a potential source of antibacterial compounds for food applications as an additive.

\section{INTRODUCTION}

Foodborne diseases involve a wide spectrum of illnesses which are caused by bacterial, viral, parasitic or chemical contamination of food. The most common causes of foodborne diseases worldwide are food infection and intoxication. Foodborne pathogens find their way into foods through cross contamination, improper handling and temperature abuse. Staphylococcus aureus and Salmonella sp. are among the common foodborne microorganisms that cause infection and intoxication [1-2]. Chemical preservatives which act as antimicrobial compounds are used to inhibit the growth of undesirable microorganisms in food. However, the demand for minimally-processed, extended shelf life foods and reports of chemical preservatives having potential toxicity led to the search for alternative sources of antimicrobial compounds by food manufacturers [3-4].

Food manufacturers involved in the production of novel functional foods often employ the addition of one or more interesting bioactive compounds usually referred to as functional ingredients to a traditional food, thereby developing and commercializing several functional foods. Microalgae are the basis of the food chain in aquatic ecosystems; with the aid of solar energy, they can use water and carbon dioxide to synthesize complex organic compounds-and subsequently accumulate and/or secrete many primary and secondary metabolites of interest [5-7]. Scenedesmus belongs to the order Sphaeropleales of the family Scenedesmaceae which is frequently dominant in freshwater lakes and rivers [8-9]. Scenedesmus sp. can exist as unicellular organisms and are also often found in coenobia of four or eight cells [10] (Fig 1).

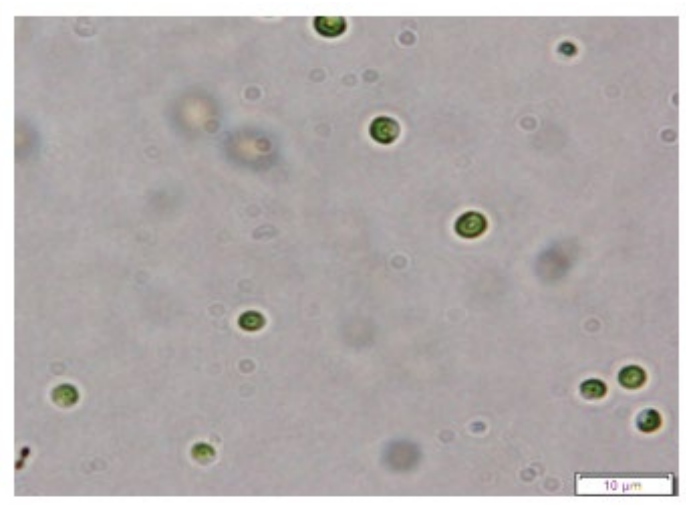

Figure 1 morphology of Scenedesmus sp. (100x magnification).
Many species of this genus are being used worldwide for various purposes due to their ability to adapt to harsh environmental conditions, ability to grow rapidly and ease of cultivation and handling [11-12]. Likewise Scenedesmus sp. have been used in many biotechnological applications due to their high nutritional content and bioactivities $[7,13]$.The potential of microalgae in biotechnological applications range from nitrogen fixation, production of bioactive and pharmaceutical compounds, health foods, and aquaculture feeds [14]. This study was carried out to evaluate the antibacterial activities of Scenedesmus sp. pigment extract on food spiked with foodborne pathogen S. aureus.

\section{EXPERIMENTAL}

2.1 Microalga culture

Scenedesmus sp. was obtained from the food technology and microbiology laboratory of Universiti Tun Hussein Onn Malaysia (UTHM) and maintained on Bold Basal Medium (BBM). The cultures were grown in Erlenmeyer flasks containing $500 \mathrm{ml}$ of BBM respectively and incubated at room temperature under light illumination from sunlight during the day. Although no aeration was provided throughout, the cultures were shaken manually few times every day to allow dispersal as well as prevent cells from sinking to the bottom.

2.2 Extraction of microalgal pigment

Scenedesmus sp. biomass was harvested following the method described [15] through centrifugation. Briefly, the concentrated biomass was placed in a tissue grinder and covered with about $2-3 \mathrm{ml} 90 \%$ acetone and macerated for $1 \mathrm{~min}$. The slurry volume was adjusted to $10 \mathrm{ml}$ with $90 \%$ acetone and steeped for at least $2 \mathrm{~h}$ at 4 in the dark after which it was centrifuged.

2.3 Estimation of chlorophyll a and b content

Pigment extract was transferred into $1 \mathrm{~cm}$ cuvette and the absorbance was measured at $750 \mathrm{~nm}, 664 \mathrm{~nm}$ and $647 \mathrm{~nm}$ and $630 \mathrm{~nm}$ using a spectrophotometer (Biomate 3S, Thermofisher Scientific USA). The absorbance reading at $750 \mathrm{~nm}$ was subtracted from the readings of $664 \mathrm{~nm}$, $647 \mathrm{~nm}$ and $630 \mathrm{~nm}$. The chlorophyll $\mathrm{a}$ and $\mathrm{b}$ content were then estimated using the following equations:

$$
\begin{aligned}
& \mathrm{Ca}=11.85(\mathrm{~A} 664)-1.54(\mathrm{~A} 647)-0.08(\mathrm{~A} 630) \\
& \mathrm{Cb}=21.03(\mathrm{~A} 647)-5.43(\mathrm{~A} 664)-2.66(\mathrm{~A} 630)
\end{aligned}
$$

$\mathrm{Ca}$ and $\mathrm{Cb}=$ concentration of chlorophyll $\mathrm{a}$ and $\mathrm{b}$ in $\mu \mathrm{g} / \mathrm{ml}$ [15]

2.4 Estimation of Carotenoid content

The method of [16] was used to determine the carotenoid content present in the same pigment extract. The extract was measured using spectrophotometer (Biomate 3S, Thermofisher Scientific USA) at $480 \mathrm{~nm}$. The carotenoid content was calculated thus; 
Carotenoid $(\mu \mathrm{g} / \mathrm{ml})=\mathrm{A} 480+(0.114 \mathrm{X} \mathrm{A663})-(0.638 \times \mathrm{A} 645)$ Where, $\mathrm{A}=$ Absorbance at respective wave length.

2.5 Determination of pigment concentration extracted

It is important to calculate and know the concentration of a working substance or solution to allow for new solutions to be created for further use in experiments. This also aids in dilution if the actual concentration of a solution is known. Below are calculations showing how the pigment extract concentration was evaluated. To calculate the concentration, weight per unit volume was used [17].

Conc. of pigment obtained $=$ Weight of Scenedesmus sp. Obtained $/$ Total volume of $90 \%$ acetone used for extraction

\subsection{Bacterial inoculum}

Using the direct colony suspension, 3-5 well isolated colonies of S. aureus cultured on Tryptic soy agar (TSA) were picked and transferred into a tube of sterilized Tryptic soy broth (TSB) with a sterilized wire loop. The bacteria were mixed well in the broth to dissolve the colonies. The turbidity of the bacterial suspension was standardized to match that of a $0.5 \mathrm{McF}$ arland standard and this corresponds to approximately $1.5 \times \llbracket 10 \rrbracket^{\wedge} 8 \mathrm{CFU} / \mathrm{ml}$. Turbidity of the actively growing broth culture was adjusted with sterile saline or broth to obtain turbidity comparable to that of the 0.5 McFarland standard. The inoculum was compared against the $0.5 \mathrm{McF}$ arland standard against a card with a white background and contrasting black lines. The adjusted innocula was used within 15 min of preparation [18].

\subsection{Preparation of fried rice}

The fried rice used in this study was prepared in the laboratory. The ingredients used in the preparation of the food include; rice, cooking oil, meat, vegetables, onions, salt, and seasoning. The raw ingredients were washed thoroughly prior to cooking. The prepared food was put into a sterile bag and then homogenized to a paste form with a stomacher.

\subsection{Preparation of food samples for antibacterial activity}

A modification of the method by [19-20] was used in spiking the food with S. aureus. Food suspension was made by weighing $10 \mathrm{~g}$ of the homogenized fried rice into $100 \mathrm{ml}$ of sterile distilled water and re-homogenized again with a homogenizer. Thereafter, $1 \mathrm{ml}$ of the food homogenate was pipetted into labeled sterile tubes and $10 \mu \mathrm{l}$ of S. aureus inoculum was added to the tubes and mixed thoroughly. Different volumes of pigment and lipid extracts $(10 \mu \mathrm{l}-100 \mu \mathrm{l})$ at different concentrations were separately pipetted into the mixture and shaken thoroughly. The mixtures were incubated at 37 [ for 2 hours and then poured into sterile plates for pour plate method using prepared Mannitol salt agar. After solidification of the samples in the agar, the plates were incubated at 37 for 24 hours. Antibacterial activity was determined after 24 hours by counting the colonies grown on the plates using a colony counter. Positive (tetracycline) and negative (solvents) controls were used and a sterility check was also carried out on the food. Counts were expressed as $\mathrm{CFU} / \mathrm{ml}$

\section{RESULTS}

The presence of three major pigments were determined in the pigment extract and their concentrations evaluated individually. Chlorophyll ' $a$ ' (39.97 \pm 1.103$) \mu \mathrm{g} / \mathrm{ml}$, chlorophyll 'b' $(13.58 \pm 1.482) \mu \mathrm{g} / \mathrm{ml}$ and carotenoid $(2.25 \pm 0.357) \mu \mathrm{g} / \mathrm{ml}$ was recorded in the freshwater microalgae Scenedesmus sp. (Fig 2).

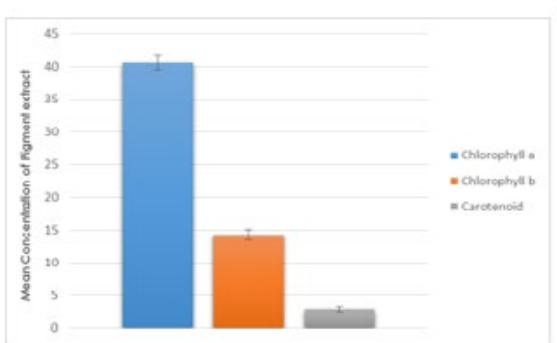

Figure 2 Mean Concentrations of photosynthetic pigments present in Scenedesmus sp.

The results revealed that the pigment extract of Scenedesmus sp. exhibited antibacterial activities against the test bacterial isolate S. aureus (ATCC 25923) when spiked in food. The highest $(P<0.05)$ bacterial count was observed in the treatment with $0.41 \mathrm{mg} / \mathrm{ml}$ and $0.81 \mathrm{mg} / \mathrm{ml}$ pigment extract as they were TMTC(Table1).On the other hand, No $(\mathrm{P}<0.05)$ bacterial counts between the samples were observed in the treatments with $2.83 \mathrm{mg} / \mathrm{ml}-4.05 \mathrm{mg} / \mathrm{ml}$ pigment extract (Table 1$)$. Thus higher $(\mathrm{P}<0.05)$ inhibitory activity of Scenedesmus sp. pigment extract was observed in the plates with $70-100 \mu \mathrm{l}(2.83 \mathrm{mg} / \mathrm{ml}-4.05 \mathrm{mg} / \mathrm{ml})$ of the extract against $\mathrm{S}$. aureus (Figure 3).

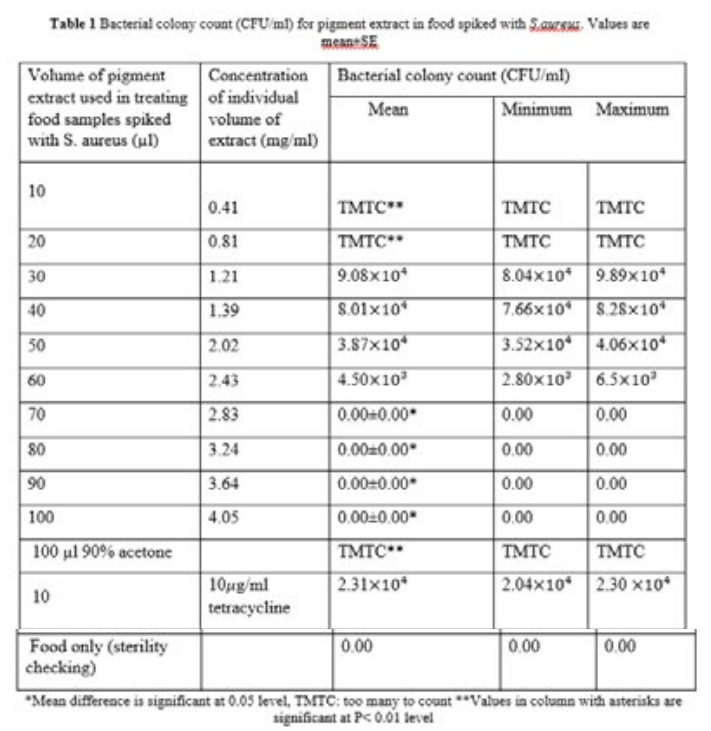
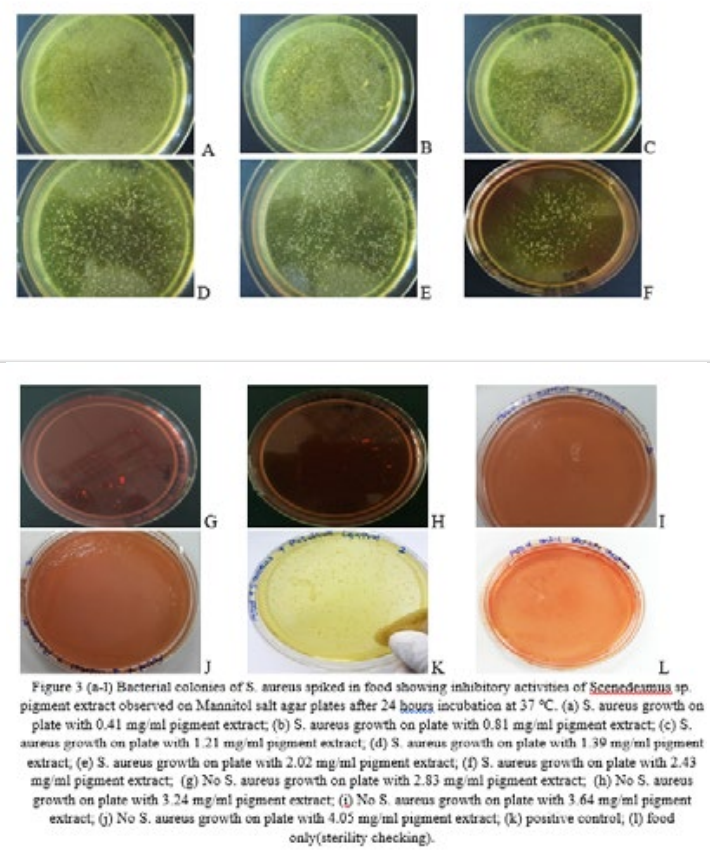

\section{DISCUSSION}

Scenedesmus sp. have been reported to produce antimicrobial substances which from the pharmaceutical's point of view, are a good source of new bioactive compounds [21]. Scenedesmus sp. is reported as being among the few members of the green algae to produce antimicrobial substances and have active and prominent antibacterial properties that inhibited the growth of several pathogenic strains of bacteria when tested against them [7]. Chlorophyll is one of the most valuable bioactive compounds that are being extracted from the microalga biomass. Due to its strong green pigment content and consumers growing preference for natural foods, since many foods tend to lose their original colors due to the chemical processes they undergo, chlorophyll is gaining importance as a food additive [22]. The exhibition of antibacterial activity was considered to be an indicator of the capability of the freshwater microalga to synthesize bioactive secondary metabolites. Chlorophylls and $\beta$ - carotene are major pigments present in microalgae that are known to act effectively as microbial growth inhibitors [23]. [24 \& 25] reported that pigments from microalgae had antibacterial effect on certain bacteria which includes S. aureus. According to [26], the Chlorophyta, or green algae, which includes Scenedesmus contains chlorophyll a, b and several carotenoids. The main objective of this study 
was to evaluate the ability of the microalga pigment extract to inhibit the growth of foodborne Staphylococcus aureus.

The antibacterial analysis of pigment extracts of Scenedesmus sp. in food spiked with bacteria showed good inhibitory activity. The antibacterial activity of the extract was evident in the reduction of the bacterial colony counts formed on the agar plate as the concentration of the pigment was increased. The antibacterial activity and efficacy of pigment extract of Scenedesmus sp. was in conformity with earlier tests done on the solid agar in which the zones of inhibition were measured [7, 27-29]. Comparisons between studies are often complicated because different authors have used a variety of methodological approaches to determine and measure potency of antibiotics with considerable variation in the inoculum, solvent and incubation conditions. It is also important to note that the solvent must be separated from the final extract, especially if the product is to be used in food applications [30]. Consumer demand has renewed the use of natural food antimicrobial agents for food preservation [31]. Many medicinal plants incorporated into food exhibit antibacterial activities which limits the growth of foodborne pathogens, thereby increasing food safety. In many cases, when an extract is mixed into food the antimicrobial effect is reduced by reaction or interaction with food components. Therefore, a greater concentration of the extracts are needed to achieve the same effect in food as it is in microbiological media [32]. The intrinsic properties of food such as; fat/protein, antioxidants, water activity, $\mathrm{pH}$, salts, other additives as well as external determinants such as; temperature, packaging as well as the characteristic of the microorganism can also influence bacteria sensitivity to the plant extracts [33-34].

\section{CONCLUSION}

Based on the data obtained, it is clear that the pigment extract shows great prospects as a source of natural antibacterial compound that can be used as food additive to inhibit the growth of foodborne pathogen S. aureus. This information can prove to be very helpful in further research and discovery of new drugs in antimicrobial therapy.

Acknowledgement

The authors would like to thank the granting body, FRGS Vot 1476 for funding the research. Gratitude is also extended to Dora Lai Jang-Ing who helped in the isolation of the microalgal species.

\section{References}

Jay, J.M. 2000. Mordern Food Microbiology. 6th edition. Aspen Publishers, Inc., Maryland. 679p

Ray, B. 2001. Fundamental Food Microbiology 2nd ed. CRC Press LLC, Florida. p.562

Conner, D.E. 1993. Naturally occurring compounds, In P.M. Davidson and A.L. Branen (eds.). Antimicrobials in Foods. 2nd ed. Marcel Dekker, Inc., NewYork. pp. 441-468

Nychas, G.J.E. 1995. Natural antimicrobials from plants, In: G.W. Gould (ed). New Methods of Food Preservation. Chapman and Hall, Glasgow. pp. 58-89. Tandeau-de-Marsac, N., Houmard, J. 1993. Adaptation of cyanobacteria to environmental stimuli: New steps towards molecular mechanisms. FEMS Microbiol Rev. 104:119-190

León, R., Martín, M., Vigara, J., Vilchez, C., and Vega, J. 2003. Microalgaemediated photoproduction of $\beta$-carotene in aqueous organic two-phase systems. Biomol Eng. 20:177-182.

Guedes, C. A., Catarina, R.B., Helena, M.A., Claudia, I.P., and Francisco, X.M. 2011. Microalgal and cyanobacterial cell extracts for use as natural antibacterial additives against food pathogens. Int. J.Food Sci. and Technol, 46(4): 862-870.

Borowitzka, M.A. and Borowitzka L.J. 1988. Dunaliella. In: Borowitzka M.A. \& Borowitzka L.J. (eds.), Micro-algal Biotechnology. Cambridge University Press: Cambridge. pp. 27-58

Guiry, M.D. 2014. Scenedesmus Meyen, 1829. In: Guiry, M.D. \& Guiry, G.M. (2014). AlgaeBase. World-wide electronic publication, National University of Ireland, Galway (taxonomic information republished from AlgaeBase with permission of M.D. Guiry). Accessed through: on 2014 08-05

Miquel, L., and Ellen, V.D. 2000. Grazer-Induced Colony Formation in Scenedesmus: Are There Costs to Being Colonial? Oikos 88(1): 111-118

Miquel, L. 2003. Phenotypic plasticity in the green algae Desmodesmus and Scenedesmus with special reference to the induction of defensive morphology. Annales de Limnologie - International Journal of Limnology, 39(2), 85-101.

Pulz, O., and Gross, W. 2004. Valuable products from biotechnology of microalgae. Applied Microbiology Biotechnology, 6: 635-648.

Chacón-Lee, T.L., and González-Marino, G.E. 2010. Microalgae for healthy foods - possibilities and challenges. Comprehensive reviews in food science and food safety, 9 (6), 655-675.

McEvoy, E., Wright, Ph. C. and Bustard, M. T. 2004. The effect of high concentration isopropanol on the growth of a solvent-tolerant strain of Chlorella vulgaris. Enzyme Microbiology Technology. 35:140-6.

APHA. (2012). Standard Methods for the Examination of Water and Wastewater, 22nd Edition. American Public Health Association, 800 I Street, NW, Washington, D.C.

Kirk J T O., Allen RL. Dependence of chloroplast pigments synthesis on protein synthetic effects on actilione. Biochem. Biphy. Res. Can. 1965; 27: 523-530.

McGahey, L. (1999). Solution concentration calculations. The College of St. Scholastica,DuluthMN. solutions/concalc.html

Lalitha, M.K. 2004. Manual on Antimicrobial Susceptibility Testing (Under the Auspices of Indian Association of Medical Microbiologists). Vellore, India: C.M.C. Vellore.

Campbell, J. 2011. High-throughput assessment of bacterial growth inhibition by optical density measurements. Curr. Prot. in Chem Biol. 3(3): 1- 20.

Oranusi, U.S., Akande, V.A., and Dahunsi, S.O. (2013). Assessment of Microbial Quality and Antibacterial Activity of Commonly used Hand Washes. J. Biol. Chem Res. 30(2): 570- 580.

Guedes, A. C., Amaro, H. M. and Malcata, F. X. (2011b), Microalgae as sources of high added-value compounds-a brief review of recent work. Biotechnol Progress, 27: 597-613. doi: 10.1002/btpr.575

Humphrey, A.M. 2004. Chlorophyll as a color and functional ingredient, Journal of Food Science, 69(5): 422-425.

Bhagavathy, S., Sumathi, P., Jancy, S.B.I., (2011), Green algae Chlorococcum humicola- a new source of bioactive compounds with antimicrobial activity. Asian journal of tropical biomedicine.S1-S7.

Fan, M., Liao, Z., Wang, R., Xu, N., (2013). Isolation and antibacterial activity of anabaena phycocyanin. African Journal of Biotechnology, 12:1869-1873. Jaya, P. G. M., Seshikala, D., Singara, C. M. A., (2007). Antibacterial Activity and Biomolecular Composition of certain Freshwater Micro-algae From River Godavari (India). Science World Journal, 2(3): 19-23.

Tomaselli, L. (2004). The microalgal cell. In: Richmond A, eds. Handbook of Microalgal Culture: Biotechnology and Applied Psychology. Oxford: Blackwell Publishing Ltd; 2004: 3-19.

Ördög, V., Stirk, W.A., Lenobel, R., Bancirova, M., Strnad, M., Van, S.J., Szigeti, J., and Nemeth, L. 2004. Screening microalgae for some potentially useful agricultural and pharmaceutical secondary metabolites. Journal of Applied Phycology, 16, 309-314

Ghasemi, Y., Moradian, A., Mohagheghzadeh, A., Shokravi, S. and Morowvat, M.H. (2007). Antifungal and antibacterial activity of the microalgae collected from paddy fields of Iran: Characterization of antimicrobial activity of Chroococcus dispersus. Journal of Biological Sciences. 7, 904-910.

Abedin, R. M. A., \& Taha, H. M., (2008). Antibacterial and Antifungal Activity of Cyanobacteria and Green Microalgae. Evbaluation of Medium Components by Plackett - Burman Design for Antimicrobial Activity of Spirulina Platensis. Global Journal of Biotechnology and Biochemistry, 3 (1): 22 - 31.

Starmans, D.A.J., and Nijhuis, H.H. 1996. Extraction of secondary metabolites from plant material: a review. Trends in Food Sci and Technol, 7:191-197. Bagamboula, C.F., Uyttendaele, M., \& Debevere, J., (2003). Antimicrobial effect of spices and herbs on Shigella sonnei and S. flexneri. Journal of Food Protein, 66: 668-673.

Smid, E.J. \& Gorris, L.G.M., (1999). Natural antimicrobials for food preservation. In: Rahman, M.S. (Ed.), Handbook of Food Preservation. Marcel Dekker, New York, pp. 285-308.

Shelef, L.A., Jyothi, E.K and Bulgarelli, M.A., (1984). Growth of enteropathogenic and spoilage bacteria in sage-containing broth and foods. Journal of Food Science, 49: (737-740) 809.

Tassou C., Drosinos, E.H., \& Nychas, G-J.E., (1995). Effects of essential oil from mint (Mentha piperita) on Salmonella enteritidis and Listeria monocytogenes in model food systems at $4{ }^{\circ} \mathrm{C}$ and $10^{\circ} \mathrm{C}$. Journal of Applied Bacteriology, 78: 593- 600 . 